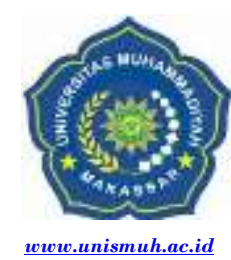

www.unismuh.ac.id
Jurnal Equilibrium Pendidikan Sosiologi

Vol V Mei No. 12017

\title{
Implikasi Sosial Pernikahan Usia Muda di Kabupaten Bone
}

\author{
Akhiruddin \\ Program Studi Pendidikan Sosiologi STKIP Mega Rezky Makassar \\ akhiruddinudin@ymail.com
}

\begin{abstract}
A young marriage is an inner bond between a man and a woman as a husband and wife for the purpose of forming a family, a happy and eternal household based on the One Supreme Godhead. This study aims to determine the impact of young marriage. This research type is qualitative decriptive, and determination of informant done with Purvosive Sampling, Technique of collecting data using observation, interview and documentation. Then analyzed by data reduction, data presentation, and verivication. The results of this study indicate that positive impacts are (1) to avoid free association, (2) lighten the life burden of one party from the family, and (3) learn to be responsible to the family and while the negative impact is (1) biologis (risk of pregnancy (2) Psychological (prolonged psychic trauma in the child's soul is difficult to cure) and (3) Sociological (immature ways of thinking that reduce harmonization in the family). (4) Population (population density) of fertile couples.

Keywords: Impact, Marriage, Young Age.
\end{abstract}

Abstrak. Pernikahan usia muda merupakan ikatan lahir batin antara seorang laki-laki dan perempuan sebagai suami-istri dengan tujuan membentuk keluarga, rumah tangga yang bahagia dan kekal berdasarkan Ketuhanan Yang Maha Esa. Penelitian ini bertujuan ini untuk mengetahui dampak pernikahan usia muda. Jenis penelitian ini yaitu dekriptif kualitatif, dan penentuan informan dilakukan dengan Purvosive Sampling, Teknik pengumpulan data menggunakan observasi, wawancara dan dokumentasi. Kemudian dianalisis secara reduksi data, penyajian data, dan verivication. Hasil penelitian ini menunjukkan bahwa dampak positif yaitu (1) supaya terhindar dari pergaulan bebas, (2) Meringankan beban hidup salah satu pihak dari keluarga, dan (3) belajar bertanggung jawab terhadap keluarga dan sedangkan dampak negatif yaitu (1) Biologis (resiko kehamilan organ reproduksi terhadap perempuan), (2) Psikologis (trauma psikis berkepanjangan dalam jiwa anak yang sulit disembuhkan) dan (3) Sosiologis (cara berpikir yang belum matang sehingga mengurangi harmonisasi dalam keluarga). (4) Kependudukan (kepadatan penduduk) terhadap pasangan usia subur (PUS).

Kata Kunci: Dampak, Pernikahan, Usia Muda. 


\section{PENDAHULUAN}

Pernikahan usia muda adalah anak yang ada pada masa peralihan di antara masa anak-anak dan masa dewasa di mana anak-anak mengalami perubahan cepat di segala bidang. Mereka bukan lagi anak-anak, baik bentuk badan, sikap dan cara berpikir dan bertindak, tetapi bukan orang dewasa yang telah matang (Fatqur, 2009). Berkaitan dengan penjelasan di atas bahwa orang yang melangsungkan pernikahan usia muda sematasemata untuk memuaskan nafsu birahi yang bertengger dalam tubuh dan jiwanya, bukan untuk meraih ketenangan, ketentraman dan sikap saling mengayomi di antara suami-istri dengan cinta dan kasih sayang yang mendalam. Namun tujuan dan hikmah pernikahan itu untuk mendapatkan anak dan keturunan yang sah. Dengan demikian, pernikahan seseorang dapat berinteraksi dengan lingkungan masyarakat lebih nyaman, tenang dan terkendali di mana semua kebutuhannya dapat dipenuhi dan tercukupkan. Akan tetapi, kenyataan di tengah masyarakat masih sering terjadi pernikahan usia muda sekalipun dilarang oleh Undang-Undang pernikahan. Pernikahan dalam usia muda ini menimbulkan masalah sosial, seperti meningkatnya perceraian sehingga jauh dari harapan masyarakat karena banyak di antara pemuda-pemudi yang melakukan pernikahan pada usia muda hanya didasari oleh perasaan cinta kasih sesaat (cinta erotis). Hal ini kemudian berdampak pada banyaknya kasus rumah tangga yang tercipta tanpa didasari persiapan yang matang baik fisik, psikis maupun sosial.

\section{METODE PENELITIAN}

Penelitian ini merupakan kualitatif yang bersifat deskriptif, untuk menggambarkan atau melukiskan situasi tentan $\mathrm{g}$ apa yang dialami masyarakat Mattirowalie Kecamatan Libureng Kabupaten Bone. Teknik penarikan sampel yang digunakan dalam penelitian ini adalah secara sengaja (Purposive Sampling), di mana purposive sampling merupakan tehnik pengambilan sampel, sumber data dengan pertimbangan berdasarkan karakteristik. Penelitian ini memilih dan memilah informan yang akan memberikan informasi yang valid tentang apa yang akan menjadi fokus penelitian, orang yang betul-betul paham tentang masalah yang akan dikaji dalam penelitian. Teknik yang digunakan untuk memperoleh data dan dibutuhkan dalam penelitian ini adalah observasi/pengamatan, metode interview (wawancara) dan metode dokumentasi. Analisis ini dilakukan dengan cara menyusun yaitu reduksi data (data reduction), penyajian data (display data), yang dikumpulkan dari berbagai pihak dan memberikan verivication untuk kesimpulan. Sedangkan teknik keabsahan data yaitu meliputi uji (a) credibility (validitas internal), (b) transferability (validitas eksternal), (c) dependability (reliabilitas) dan (d) confirmability (objektivitas).

\section{PEMBAHASAN}

Pernikahan adalah suatu bentuk ibadah di mana seorang laki-laki dan perempuan melakukan akad dengan tujuan meraih kehidupan yang sakinah (tenang, damai), mawaddah (saling mencintai dan penuh kasih sayang), serta warahmah (kehidupan yang dirahmati Allah) (Thobroni \& Munir, 2010: 11).

\section{a. Pernikahan Pada Usia Muda Menurut Sosiologi}

Usia muda adalah anak yang menginjak antara masa anak-anak ke masa dewasa. Masa tersebut dianggap juga sebagai masa transisi artinya orang yang harus menyelesaikan krisis identitas antara penemuan identitas dan kebingungan identitas, secara sosiologis terdapat antara umur 12 hingga 20 tahun. (Damsyar, 2011: 87). Sedangkan usia dewasa adalah orang dewasa yang harus menyelesaikan krisis identitas antara keintiman dan isolasi artinya siap untuk mengalami keintiman dan kesetiakawanan. Dia dapat berjanji setia pada hubungan pasangan bahkan apabila mereka menuntut bermacam pengorbanan dan kompromi yang berarti secara sosiologi terdapat antara umur 21 hingga 35 tahun. (Damsyar, 2011: 87-89).

b. Pernikahan Usia Muda Menurut UU No. 1 Tahun 1974 Tentang Pernikahan

Berikut ini akan diuraikan beberapa usia pernikahan, menurut UU Pernikahan, yakni : 
a) Usia pernikahan menurut UU No. 1 Tahun 1974 tentang pernikahan diatur dalam ketentuan pasal 7 (ayat 1-2) sebagai berikut :

1) Pernikahan hanya diizinkan jika pihak laki-laki sudah mencapai umur 19 tahun dan pihak perempuan mencapai umur 16 tahun.

2) Dalam hal penyimpangan terhadap ayat (1) pasal ini dapat meminta dispensasi kepada pengadilan atau pejabat lain, yang ditunjuk oleh kedua orang tua pihak laki-laki maupun pihak perempuan.

b) Menurut UU No. 1 Tahun 1974 tentang pernikahan pada pasal 6 ayat (1-4) menjelaskan bahwa syarat-syarat pernikahan adalah sebagai berikut:

1) Pernikahan harus didasarkan atas persetujuan kedua calon mempelai.

2) Untuk melangsungkan pernikahan, seseorang yang belum mencapai Usia 21 tahun harus mendapat izin kedua orang tuanya.

3) Dalam hal salah seorang dari kedua orang tua telah meninggal dunia atau dalam keadaan tidak mampu menyatakan kehendaknya, maka izin dimaksud ayat (2) pasal ini cukup diperoleh dari orang tua yang masih hidup dan atau orang tua yang mampu menyatakan kehendaknya.

4) Dalam hal kedua orang tua telah meninggal dunia atau dalam keadaan tidak mampu menyatakan kehendaknya maka izin diperoleh dari wali, orang yang memelihara atau keluarga yang mempunyai hubungan darah dalam garis keturunan lurus ke atas selama mereka masih hidup dan dalam keadaan dapat menyatakan kehendaknya.

Syarat-syarat pernikahan di atas merupakan syarat-syarat pernikahan secara material, yaitu syarat-syarat yang berkaitan dengan batas umur seseorang untuk melangsungkan pernikahan. (Prodjohamidjojo, 2007).

\section{c. Pernikahan Usia Muda Menurut Hukum Islam}

Dalam kacamata Islam ukuran kedewasaan seorang anak didasarkan atas ukuran aqil baligh orang yang belum dewasa atau masih di bawah umur. Dalam hukum Islam disebut dengan sabi, sedangkan yang tergolong dewasa disebut aqil baligh. Dalam sebuah hadist, Rasulullah SAW bersabda :

"Wahai para pemuda, barang siapa di antara kalian telah mencapai ba'ah, nikahlah. Karena sesungguhnya, pernikahan itu lebih mampu menahan pandangan mata dan menjaga kemaluan. Dan, barang siapa belum mampu melakukannya, hendaklah dia berpuasa karena sesungguhnya puasa itu akan meredakan gejola hasrat seksual". H.R.Muslim., (Labib \& Qisthi 2005: 347).

Berdasarkan hadist tersebut, Rasulullah SAW menggunakan kata "pemuda", yakni orang yang telah mencapai masa aqil baligh dan usianya di bawah 30 tahun. Jadi, pernikahan usia muda menurut kacamata Islam apabila pernikahan tersebut dilangsungkan pada usia di bawah 12-15 tahun (bagi perempuan umumnya) dan 14-17 tahun (bagi laki-laki umumnya). Di atas umur tersebut, agama Islam bahkan menganjurkan untuk dilangsungkannya pernikahan karena sudah dianggap mencapai umur aqil baligh. (Adhim, 2002).

\section{d. Pernikahan Usia Muda Menurut Psikologi}

Kekhawatiran dan kecemasan timbulnya persoalan-persoalan psikis dan sosial, bahwa pernikahan diusia muda dan masih di bangku sekolah bukan sebuah penghalang untuk meraih prestasi yang lebih baik, bahwa usia bukan ukuran utama untuk menentukan kesiapan mental dan kedewasaan seseorang, bahwa menikah bias menjadi solusi alternatif untuk mengatasi kenakalan kaum remaja yang kian tak terkendali. (Makmun Mubayidh, 2006). Teori tertua tentang adanya fase-fase perkembangan dikemukakan oleh Aristoteles. Aristoteles membagi fase-fase perkembangan atas 7 tahun, sehingga dari masa anak kecil sampai remaja terbagi atas tahapan (Mubin \& Cahyadi, 2006: 54) yaitu sebagai berikut : (a) Masa Anak kecil dari umur 0-7 tahun. (b) Masa kanak-kanak dari umur 7-14 tahun. (c) Masa remaja/Puber dari umur 14-21 tahun.

Alfiyah, (2010: 25) Ada beberapa faktor yang menyebabkan terjadinya pernikahan usia muda yang sering dijumpai di lingkungan masyarakat yaitu: 
a. Kemauan sendiri, karena keduanya merasa sudah saling mencintai dan sehingga mereka yang telah mempunyai pasangan atau kekasih terpengaruh untuk melakukan pernikahan di usia muda.

b. Ekonomi, pernikahan usia muda karena keadaan keluarga yang hidup digaris kemiskinan, untuk meringankan beban tuanya maka anak perempuannya dinikahkan dengan orang yang dianggap mampu.

c. Pendidikan, rendahnya tingkat pendidikan maupun pengetahuan orang tua, dan masyarakat, menyebabkan adanya kecenderungan menikahkan anak masih di bawah umur.

d. Keluarga, karena orang tua tidak sanggup menyekolahkan anaknya sehingga ia cepatcepat dinikahkan, juga karena kurangnya kemauan anak untuk melanjutkan sekolah dan faktor takut jadi perawan tua, maka satusatunya jalan keluar adalah dinikahkan secepatnya manakala ada jodohnya.

e. Tradisi, pernikahan usia muda terjadi karena masih memandang hal yang wajar apabila pernikahan dilakukan pada usia anak-anak atau remaja, bahwa sudah menjadi tradisi yang sulit untuk dihilangkan dalam lingkungan masyarakat tersebut.

Bahwa pernikahan usia muda merupakan suatu tindakan sosial atau perilaku sosial yang sesuai, sebagaimana diungkapkan oleh Weber (Johnson 1986: 221) mengatakan bahwa, tindakan sosial merupakan tindakan yang terjadi ketika individu meletakkan makna subjektif pada tindakan mereka. Seringkali tindakan ini dilakukan tanpa perencanaan matang dan tanpa kesadaran penuh dan dapat dikatakan tindakan yang dilakukan merupakan reaksi spontanitas atas suatu peristiwa sehingga tidak sesuai dengan tujuan dari pernikahan itu sendiri. Seperti bertindak untuk melakukan pernikahan usia muda demi melampiaskan nafsu mereka tanpa perencanaan atau kesiapan yang matang.

Bahwa perilaku penyimpangan adalah perilaku dari para warga masyarakat yang dianggap tidak sesuai dengan tata aturan atau norma sosial yang berlaku. Secara sederhana kita memang dapat mengatakan, bahwa seseorang berperilaku menyimpang apabila menurut anggapan sebagian besar masyarakat (minimal disuatu kelompok atau komunitas tertentu) perilaku atau tindakan tersebut di luar aturan, nilai, atau norma sosial yang berlaku.

Terkait dengan apa yang diuraikan di atas, Setiadi dan Kolip (2011: 193) dengan mengutip pendapatnya Durkheim atas perilaku dinilai negatif oleh masyarakat. Bahwa perilaku menyimpang bukanlah perilaku yang semata-mata tak normal dan melulu bersifat negatif, menurutnya, perilaku menyimpang memiliki konsribusi positif bagi kelangsungan masyarakat secara keseluruhan. Oleh sebab itu, secara garis besar bentuk perilaku menyimpang dibedakan menjadi dua macam, yaitu: (a) Penyimpangan positif adalah penyimpangan yang terarah pada nilai-nilai sosial yang ideal (didambakan) walaupun cara atau tindakan yang dilakukan tersebut seolah-olah kelihatan menyimpang dari norma-norma yang berlaku, padahal sebenarnya adalah tidak menyimpang. (b) Penyimpangan negatif adalah kecenderungan bertindak ke arah nilai-nilai sosial yang dipandang rendah dan akibatnya selalu buruk. Oleh karena itu, fenomena perilaku menyimpang dalam kehidupan bermasyarakat memang menarik untuk dibicarakan. Akan tetapi, pada dasarnya perilaku menyimpang adalah semua perilaku manusia yang dilakukan baik secara individual maupun secara kelompok tidak sesuai dengan nilai dan norma yang berlaku di dalam kelompok tersebut.

Adapun pilosofis orang bugis tentang pernikahan yaitu persyaratan seorang laki-laki dan perempuan yang akan menikah yaitu seorang lakilaki, yakni kalloloni baso naulleni tappi gajang artinya sudah dianggap dewasa kalau mampu melindungi keluarganya. Sedangkan perempuan yakni anakdarani besse naullewi matulili $r i$ dapurengnge wekka pitu artinya mampun menguasai wilayah dapur kalau kemampuan yang dimiliki untuk seorang perempuan dewasa (Andi Ima Kesuma, 2004). 


\section{KESIMPULAN}

Dampak positif yaitu (1) supaya terhindar dari pergaulan bebas, (2) Meringankan beban hidup salah satu pihak dari keluarga, dan (3) belajar bertanggung jawab terhadap keluarga. Dampak negatif yaitu (1) Biologis (resiko kehamilan organ reproduksi terhadap perempuan),(2) Psikologis (trauma psikis berkepanjangan dalam jiwa anak yang sulit disembuhkan) dan (3) Sosiologis (cara berpikir yang belum matang sehingga mengurangi harmonisasi dalam keluarga). (4) Kependudukan (kepadatan penduduk) terhadap pasangan usia subur (PUS).

\section{DAFTAR PUSTAKA}

[1] Alfiyah. (2010). Sebab-Sebab Pernikahan Dini, (Online), Http//Alfiyah.Student.-umm.ac.id. (Diakses Pada Tanggal 10 Oktober 2014).

[2] Bungin, Burhan. (2010). Penelitian Kualitatif: "Komunikasi, Ekonomi, Kebijakan Publik, dan Ilmu Sosial Lainnya". Jakarta: Prenada Media Group.

[3] Damsar. (2011). Pengantar Sosiologi Pendidikan. Jakarta: Kencana Prenada Media Group.

[4] Fatimah, Enung. (2006). Psikologi Perkembangan (Perkembangan Peserta Didik). Bandung: CV Pustaka Setia.

[5] Fatqur. 2009. Perkawinan Di Usia Muda, (Online), Http://Blogspot.Com/-2009/05/Html. (Diakses 28 Okteber 2014).

[6] Fransiska. (2010). Dampak Pernikaha Diusia Muda. (Online). Http://Fransiska-Limantata. Blogspot. Com/2010/01/Dampak-Pernikahan-Di-UsiaMuda-Terhadap. Html (Diakses Pada Tanggal 5 Juni 2014).

[7] Hutami, (2011). Kepadatan Penduduk. (Online). Http://Hutami-Putri.Blogspot.Com /2011/03/Kepadatan-Penduduk.Html. (Diakses Pada Tanggal 5 Juni 2014).

[8] Kesuma, Andi Ima. (2004). Perkawinan Adat Luwu Sebuah Transformasi Budaya Kedatuan Luwu. Makassar: Pemda Luwu.

[9] Kesuma, Andi Ima. (2012). Moral Ekonomi (Manusia) Bugis. Makassar: Rayhan Intermedia.

[10] Labib, \& Qisthi. (2005). Risalah Fiqih Wanita. Surabaya: Bintang Usaha Jaya.

[11] Mubayidh, Makmun. (2006). Kecerdasan \& Kesehatan Emosional Anak. Jakarta: Pustaka AlKautsar.

[12] Mubin, \& Cahyadi. (2006). Psikologi Perkembangan. Yogyakarta: PT Ciputat Press Group.

[13] Nonci. (2002). Upacara Adat Istiadat Mayarakat Bugis. Makassar: CV Aksara.
[14] Prodjohamidjojo, M. (2007). Hukum Perkawinan Indonesia. Jakarta: Karya Gemilang.

[15] Setiadi, M. Elly \& Kolip, Usman. (2011). Pengantar Sosiologi, Pemahaman Fakta dan Gejala Permasalahan Sosial: Teori, Aplikasi, dan Pemecahannya. Jakarta: Prenada Media Group.

[16] Sugiyono. (2010). Metode Penelitian Kuantitatif, Kualitatif dan $R \& D$. Bandung. Alfabeta.

[17] Syarifuddin, Amir. (2011). Hukum Perkawinan Islam di Indonesia. (Cetakan Ke Tiga). Jakarta: Kencana Prenada Media Group.

[18] Thobroni, \& Munir, A. (2010). Meraih Berkah Dengan Menikah. Yogyakarta: Pustaka Marwa.

[19] Undang-Undang Perkawinan Indonesia. (2007). Wacana intelektual. 